\title{
Financial Policy Announcement Efficiency in Financial Crisis
}

\author{
Han Ching Huang ${ }^{1}$, Yong Chern $\mathrm{Su}^{2} \&$ Wen Chen Chang ${ }^{2}$ \\ ${ }^{1}$ Department of finance, Chung Yuan Christian University, Taoyuan, Taiwan. \\ ${ }^{2}$ Department of finance, National Taiwan University, Taipei, Taiwan. \\ Correspondence: Han Ching Huang, Department of finance, Chung Yuan Christian University, Taoyuan, Taiwan.
}

Received: April 18, 2016

doi:10.11114/aef.v3i3.1598

\author{
Accepted: April 29, 2016 \\ Available online: May 9, 2016 \\ URL: http://dx.doi.org/10.11114/aef.v3i3.1598
}

\begin{abstract}
In 2008 financial crisis, stock market turned highly volatile while U.S. government had proposed a series of policies rescuing the economy. This study examines convergence to market efficiency from government financial policies. We find a significant impact of contemporaneous order imbalance on return, while the relation between return and lagged imbalances is insignificant, implying that lagged order imbalances have no predictability on return. From a time-varying GARCH model, we find that explaining power of order imbalance on return declining, implying that volatility plays an important role in return-order imbalance relation. We take a further step to find that there is no strong direct relationship between order imbalances and stock volatility. The story casts on market maker behaviors. Market makers accommodate high inventory levels to mitigate stock volatility on financial policies announcements. An imbalance based trading strategy we develop fails to beat the market. It supports financial policy announcement efficiency.
\end{abstract}

Keywords: Order imbalance; Market efficiency; Causality relationship; Policy Announcement; Financial crisis

\section{Introduction}

For many decades, market efficiency has been an interesting issue among economists, investors and policy-makers. Malkiel and Fama (1970) define that an efficient market is characterized as one in which prices fully reflect all available information. In other words, there would be no indicator could predict the movement of the stock prices and no trading strategy could earn abnormal return in an efficient market, since all relevant information is included in the stock prices when revealed.

Prior studies generally support the notion that markets are efficient insofar as widespread profitable trading opportunities do not persist for long. However, under the 2008 financial crisis, the volatility of stock market increases dramatically, demanding the government's actions. U.S. government had proposed a series of policies rescuing the economy, for instance, Fed lending up to $\$ 85$ billion to the American International Group (AIG), the government's $\$ 700$ billion emergency rescue bailout, Fed three-times lowering the target rates, etc. These policies have significant influence on the stability of stock markets. In this study, we investigate the impact of financial policies on stock market and convergence to market efficiency in policy announcements.

Grossman (1976) and Grossman and Stiglitz (1980) argue that market prices cannot fully incorporate all information since informed investors take advantage of deviations of prices from fundamental values. Hillmer and Yu (1979) argue that it takes time for investors to ascertain whether there is information about values. Therefore, the information cannot be incorporated into stock prices instantaneously.

Kyle (1985) conducts a dynamic model of insider trading with sequential auctions. He finds that the insider who has private information can make positive profits by exploiting his monopoly power. Meanwhile, the noise traders place their orders by providing imitation of insider's trading which conceals insider's trading from noise trading. And all of the insider's private information is incorporated into stock prices by the end of the continuous auction. Holden and Subrahmanyam (1992) extend Kyle's model to a multi-period auction model, in which multiple informed traders share the same private information. The competition among informed traders causes the revelation of private information more quickly. Moreover, the speed of information revelation is higher with a deeper market.

Wang (1993) argues that investors maximize their profits by extracting information from prices. He finds that the existences of uninformed traders increase the risk premium and supply shocks affect risk premium only under information asymmetry. Moreover, information asymmetry increase volatility and have negative autocorrelation in 
returns. Barclay and Warner (1993), Wang (1994), Foster and Viswamathan (1994), Foster and Viswanathan (1996) share the same arguments.

Busse and Green (2002) find that prices of stocks respond to the news on the financial television network CNBC within one or two minutes. They argue that although security prices do not fully reflect all available information instantaneously, the market is efficient enough that a trader cannot generate profits based on widely disseminated news unless he acts almost immediately.

However, Chordia et al. (2005) shows that market do not converge to efficiency immediately while examining the process of convergence. They document that order imbalances do predict future returns over very short intervals, but the extent of this predictability declines markedly over the sample period. In addition, the market's ability to absorb order imbalances is greater in liquid periods than in illiquid ones. Andrade et al.. (2008) argue that positive trading imbalance of one stock is linked to its price increasing and later reverting. The same trading imbalance is also linked to other stocks experiencing predictable price reversals. And after controlling for cash flow volatilities, stocks with more volatile trading imbalances have more volatile returns.

In this study, we study convergence to market efficiency of financial policy announcements and how the information is incorporated into stock prices. We examine whether order imbalances have a significant influence on stock returns and how long it lasts. We also develop an imbalance based trading strategy to test market efficiency in financial policy announcements,

The empirical results show a significantly negative lagged-one imbalance in unconditional return-order imbalance relation and a significantly positive influence on current return, while the coefficients of lagged-one imbalances are significantly negative in conditional return-order imbalance relation, which supports Chordia and Subrahmanyam (2004).

However, in a time varying GARCH model, the explaining power of order imbalance on stock return is declining. We suspect that volatility plays an important role in return-order imbalance relation, especially in volatile markets in financial crisis. We take a further step to investigate volatility-order imbalance relation and document an insignificant relation between order imbalances and volatility. The possible explanation is that market makers mitigate stock price volatility in financial policy announcements through high inventory levels.

From our imbalance based trading strategy, we find that only strategies for five and ten minute intervals are able to beat the market and the abnormal returns vanish in next period. It supports the convergence to market efficiency. In order to explore the story behind the convergence, we employ a nested causality approach to examine the dynamic return-order imbalance relationship during the price-formation process. The results explain convergence to market efficiency in policy announcements during 2008 financial crisis.

Our study proceeds as follows. Section 2 describes data and methodology. Section 3 presents the empirical results and Section 4 concludes.

\section{Data and Methodology}

We collect financial policy announcements from Board of Governors of the Federal Reserve System, listed in Appendix 1. There are 120 stocks sharing financial policy announcement effects in our sample. We find intraday trading data, including bid price, ask price, trading prices and volume from Trades and Automated Quotations (TAQ). Our sample period ranges from Sep. 15, 2008 (failure of Lehman brothers) to Dec. 31, 2008.

To be included in our sample, the stocks must meet the following criteria:

a) The firm shall be included in the TAQ.

b) Stocks that are not actively traded on the announcement date will be discarded.

c) If there are stock repurchases, stock splits, reverse splits, and dividend payoffs on the stocks, we exclude them from our sample.

We follow Lee and Ready (1991) trade assignment algorithm to get 5 minutes, 10 minutes, and 15 minutes order imbalances. Average return is $-2.073 \%$, with a median of $-1.097 \%$.

We employ a time varying GARCH model to examine return-order imbalance relation three different time intervals.

$$
\begin{aligned}
& \mathrm{R}_{\mathrm{t}}=\alpha+\beta^{*} \mathrm{OI}_{\mathrm{t}}+\varepsilon_{\mathrm{t}} \\
& \varepsilon_{\mathrm{t}} \mid \Omega_{\mathrm{t}-1} \sim \mathrm{N}\left(0, \mathrm{~h}_{\mathrm{t}}\right) \\
& \mathrm{h}_{\mathrm{t}}=\mathrm{A}+\mathrm{B} \mathrm{h}_{\mathrm{t}-1}+\mathrm{C} \varepsilon_{\mathrm{t}-1}^{2}
\end{aligned}
$$

where, $R_{t}$ is the return at time $t$, and is defined as $\ln (\mathrm{Pt} / \mathrm{Pt}-1), \mathrm{OI}_{t}$ denotes the explanatory variable, order imbalance, $\beta$ is the coefficient describing impact of order imbalance on stock return, $\varepsilon_{t}$ is the residual value of the stock return at time $t$, 
$\mathrm{h}_{\mathrm{t}}$ is the conditional variance at time $\mathrm{t}$, And $\alpha, \mathrm{A}, \mathrm{B}$ and $\mathrm{C}$ are coefficients.

We expect a positive $\beta$ return-order imbalance relation according to Chordia and Subrahmanyam(2004). In addition, we examine how long it takes for convergence to market efficiency. We make a further step employing a similar GARCH with order imbalance in conditional variance equation to examine volatility-order imbalance relation in three different time intervals (5-min, 10-min, and 15-min). We expect a significant positive coefficient $\gamma$ because a large order imbalance is positively associated with a large volatility.

Finally, in order to explain the story behind convergence to market efficiency, we employ a nested causality to explore the dynamic causal relationship between returns and order imbalances. According to Chen and Wu (1999), we define four relationships between two random variables, $x_{1}$ and $x_{2}$, in terms of constraints on the conditional variances of $x_{1(T+1)}$ and $x_{2(T+1)}$ based on various available information sets, where $x_{i}=\left(x_{i 1}, x_{i 2}, \ldots, x_{i T}\right), i=1,2$, are vectors of observations up to time period $T$.

Definition 1: Independency, $x_{1} \wedge x_{2}$ :

$x_{1}$ and $x_{2}$ are independent if

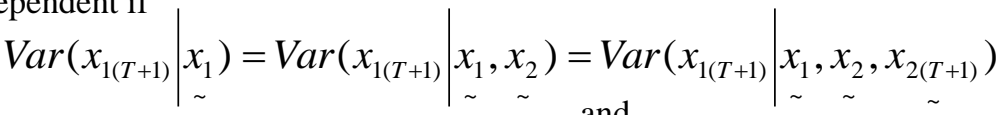

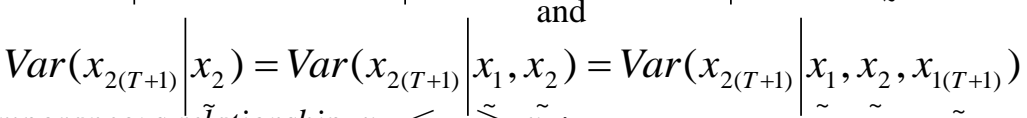

Definition 2: Contemporaneous relationship, $x_{1}<-\tilde{>} \tilde{x_{2}}$ :

$x_{1}$ and $x_{2}$ are contemporaneously related if

$$
\begin{aligned}
& \operatorname{Var}\left(x_{1(T+1)} \mid x_{1}\right)=\operatorname{Var}\left(x_{1(T+1)} \mid x_{1}, x_{2}\right) \\
& \operatorname{Var}\left(x_{1(T+1)} \mid \tilde{x}_{\sim}^{\tilde{x}_{1}, x_{2}}\right)>\operatorname{Var}(x_{1(T+1)} \tilde{\sim}_{\sim}, \underbrace{}_{\sim}, \underbrace{}_{2(T+1)})
\end{aligned}
$$

and

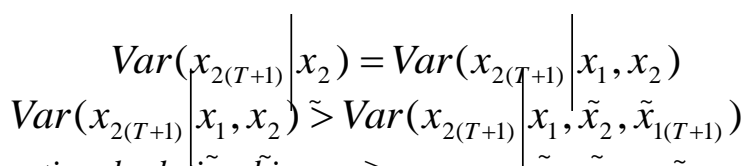

Definition 3: Unidirectional relationship, $x_{1}=>x_{2}$ :

There is a unidirectional relationship from $x_{1}$ to $x_{2}$ if

Definition 4: Feedback relationship, $x_{1} \underset{<}{=}>x_{2}$ :

$$
\begin{aligned}
& \operatorname{Var}\left(x_{1(T+1)} \mid \begin{array}{l|l}
\left.x_{1}\right)=\operatorname{Var}\left(x_{1(T+1)}\right. & \mid \\
x_{1}, x_{2}
\end{array}\right)
\end{aligned}
$$

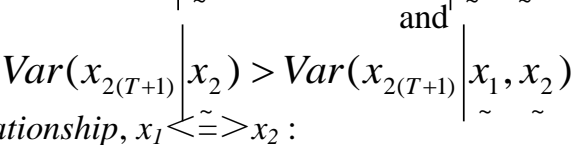

There is a feedback relationship between $x_{1}$ and $x_{2}$ if

$$
\begin{array}{l|l|l}
\operatorname{Var}\left(x_{1(T+1)}\right. & \left.x_{\sim}\right)>\operatorname{Var}\left(x_{1(T+1)}\right. & \begin{array}{l}
x_{1}, x_{2} \\
\sim \\
\sim
\end{array} \\
\operatorname{Var}\left(x_{2(T+1)}\right. & \left.x_{2}\right)>\operatorname{Var}\left(x_{2(T+1)}\right. & \left.\begin{array}{l}
x_{1}, x_{2} \\
x_{2}
\end{array}\right)
\end{array}
$$

To explore the dynamic relationship within a bi-variate system, we form the five statistical hypotheses in Table 1 where the necessary and sufficient conditions corresponding to each hypothesis are given in terms of constraints on the parameter values of the VAR model.

To determine whether there exists a specific causal relationship, we use a systematic multiple hypotheses testing method. Unlike the traditional pair-wise hypothesis testing approach, this testing method avoids the potential bias induced by restricting the causal relationship to a single alternative

\section{Table 1 Hypotheses on the dynamic relationship of a bivariate system}

The bivariate VAR model may be expressed as : $\left[\begin{array}{cc}\phi_{11}(L) & \phi_{12}(L) \\ \phi_{21}(L) & \phi_{22}(L)\end{array}\right]\left[\begin{array}{l}x_{1 t} \\ x_{2 t}\end{array}\right]=\left[\begin{array}{l}\varepsilon_{1 t} \\ \boldsymbol{E}_{2 t}\end{array}\right]$ where $x_{1 t}$ and $x_{2 t}$ are mean

adjusted variables. The first and second moments of the error structure, $\underset{\sim}{\boldsymbol{E}_{t}}=\left(\boldsymbol{E}_{1 t}, \boldsymbol{E}_{2 t}\right)^{\prime}$ are $\Sigma=\left[\begin{array}{ll}\sigma_{11} & \sigma_{12} \\ \sigma_{21} & \sigma_{22}\end{array}\right]$ that 


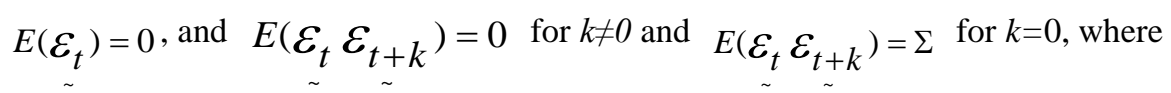

The causal relationships are defined as follows: $\wedge$ represents independency; $\langle-\rangle$ is the contemporaneous relationship; $\neq>>$ is the negation of a unidirectional relationship; $<=>$ is the feedback relationship; $\neq>>$ is the negation of a strong unidirectional relationship where $\sigma_{12}=\sigma_{21}=0$; and $\langle<=>>$ is a strong feedback relationship where $\sigma_{12}=\sigma_{21}=0$.

\begin{tabular}{ll}
\hline Hypotheses & The VAR test \\
$\mathrm{H}_{1}: \mathrm{x}_{1} \wedge \mathrm{x}_{2}$ & $\varphi_{12}(\mathrm{~L})=\varphi_{21}(\mathrm{~L})=0$, and $\sigma_{12}=\sigma_{21}=0$ \\
$\mathrm{H}_{2}: \mathrm{x}_{1}<->\mathrm{x}_{2}$ & $\varphi_{12}(\mathrm{~L})=\varphi_{21}(\mathrm{~L})=0$ \\
$\mathrm{H}_{3}: \mathrm{x}_{1} \neq>\mathrm{x}_{2}$ & $\varphi_{21}(\mathrm{~L})=0$ \\
$\mathrm{H}_{3}^{*}: \mathrm{x}_{2} \neq>\mathrm{x}_{1}$ & $\varphi_{12}(\mathrm{~L})=0$ \\
$\mathrm{H}_{4}: \mathrm{x}_{1}<=>\mathrm{x}_{2}$ & $\varphi_{12}(\mathrm{~L}) * \varphi_{21}(\mathrm{~L}) \neq 0$ \\
$\mathrm{H}_{5}: \mathrm{x}_{1} \neq>>\mathrm{x}_{2}$ & $\varphi_{21}(\mathrm{~L})=0$, and $\sigma_{12}=\sigma_{21}=0$ \\
$\mathrm{H}_{6}: \mathrm{x}_{2} \neq>>\mathrm{x}_{1}$ & $\varphi_{12}(\mathrm{~L})=0$, and $\sigma_{12}=\sigma_{21}=0$ \\
$\underline{H}_{7}: \mathrm{x}_{1}<<=>>\mathrm{x}_{2}$ & $\varphi_{\underline{12}}(\mathrm{~L}) * \varphi_{\underline{21}}(\mathrm{~L}) \neq 0$, and $\sigma_{\underline{12}}=\sigma_{21}=0$
\end{tabular}

hypothesis. To implement this method, we employ the results of several pair-wise hypothesis tests. For instance, in order to conclude that $x_{1}=>x_{2}$, we need to establish that $x_{1}<\neq x_{2}$ and to reject that $x_{1} \neq>x_{2}$. To conclude that $x_{1}<->$ $x_{2}$, we need to establish that $x_{1}<\neq x_{2}$ as well as $x_{1} \neq>x_{2}$ and also to reject $x_{1} \wedge x_{2}$. In other words, it is necessary to examine all five hypotheses in a systematic way before we draw the conclusion that a dynamic relationship exists. The following presents an inference procedure that starts from a pair of the most general alternative hypotheses.

Our inference procedure for exploring the dynamic relationship is based on the principle that a hypothesis should not be rejected unless there is sufficient evidence against it. In the causality literature, most tests intend to discriminate between independency and an alternative hypothesis. The primary purpose of the literature cited above is to reject the independency hypothesis. On the contrary, we intend to identify the nature of the relationship between two financial series. The procedure consists of four testing sequences, which implement a total of six tests (denoted as (a) to (f)), where each test examines a pair of hypotheses. The four testing sequences and six tests are summarized in a decision-tree flow chart in Table 2.

\section{Empirical Results}

\subsection{Unconditional return-order imbalance OLS relation}

The empirical results of unconditional return-order imbalance relation are presented in Table 3. The positive and significant percent of lagged-one imbalance at the 5\% significant level are $3.57 \%, 0.89 \%$, and $2.68 \%$ for 5-, 10-, and 15-min intervals respectively. The prediction power of our empirical findings, however, is too low to consistent with the result of Chordia and Subrahmanyam (2004). To our surprise, the significantly negative percent of lagged-one imbalance at $10 \%$ significant level are $11.61 \%, 10.71 \%$, and 5.36\% for 5-, 10-, and 15-min intervals respectively, which are larger than the percentages of positive and significant coefficients.

The possible explanation is as follows. When government announces financial policies, some good news spread out and boosts the stock price. Informed traders actively place orders by herding or spreading their orders out over time, which causes a huge positive order imbalance. Confronted by the

Table 2 Test flow chart of a multiple hypothesis testing procedure

Five groups of dynamic relationship are identified: independency $(\wedge)$ the contemporaneous relationship $(\leftrightarrow)$ the unidirectional relationship $(\Rightarrow$ or $\Leftarrow)$ ) and feedback relationship $(<=>$ ). To determine a specific causal relationship, we use a systematic multiple hypotheses testing method. Unlike the traditional pairwise hypothesis testing, this testing method avoids the potential bias induced by restricting the causal relationship to a single alternative hypothesis. In implementing this method, we need to the employ results of several pairwise hypothesis tests. For instance, in order to conclude that $x_{1}=>x_{2}$, we need to establish that $x_{1}<\neq x_{2}$ and to reject $x_{1} \neq>x_{2}$. To conclude that $x_{1}$ $<->x_{2}$, we need to establish that $x_{1}<\neq x_{2}$ as well as $x_{1} \neq>x_{2}$ and also to reject $x_{1} \wedge x_{2}$. In other words, it is necessary to examine all five hypotheses in a systematic way before a conclusion regarding the dynamic relationship can be drawn. 


\begin{tabular}{|c|c|c|}
\hline $\begin{array}{l}\text { Test Sequence I } \\
\text { (a) } \mathrm{H}_{3} \text { vs. } \mathrm{H}_{4} \\
\text { (b) } \mathrm{H}_{3}{ }^{*} \text { vs. } \mathrm{H}_{4}\end{array}$ & $\begin{array}{l}\rightarrow \\
\rightarrow\end{array}$ & $\begin{array}{l}\mathrm{E}_{1}: \text { (a) reject } \mathrm{H}_{3} \text {, (b) reject } \mathrm{H}_{3}{ }^{*} \rightarrow \mathrm{x}_{1}<=>\mathrm{x}_{2} \\
\mathrm{E}_{2}: \text { (a) reject } \mathrm{H}_{3}, \text { (b) not reject } \mathrm{H}_{3}{ }^{*} \rightarrow \mathrm{x}_{1} \Rightarrow \mathrm{x}_{2} \\
\mathrm{E}_{3}: \text { (a) not reject } \mathrm{H}_{3} \text {, (b) reject } \mathrm{H}_{3}{ }^{*} \rightarrow \mathrm{x}_{1} \Leftarrow \mathrm{x}_{2}\end{array}$ \\
\hline
\end{tabular}

$\mathrm{E}_{4}$ : (a) not reject $\mathrm{H}_{3}$

(b) not reject $\mathrm{H}_{3}{ }^{*}$

Test Sequence II
(c) $\mathrm{H}_{2}$ vs. $\mathrm{H}_{3}{ }^{*}$
(d) $\mathrm{H}_{2}$ vs. $\mathrm{H}_{3}{ }^{\downarrow}$
\[ \]

$\mathrm{E}_{7}$ : (c) reject $\mathrm{H}_{2}$

(d) reject $\mathrm{H}_{2}$<smiles>[CH]</smiles>

Test Sequence III

(e) $\mathrm{H}_{2}$ vs. $\mathrm{H}_{4}$

$\mathrm{E}_{9}$ :(e) reject $\mathrm{H}_{2}$
$\downarrow$
$\mathrm{x}_{1}<=>\mathrm{x}_{2}$ $\rightarrow \quad \mathrm{E}_{5}:$ (c) reject $\mathrm{H}_{2}$, (b) not reject $\mathrm{H}_{2} \rightarrow \quad \mathrm{x}_{1} \Leftarrow \mathrm{x}_{2}$

$\rightarrow \quad \mathrm{E}_{6}:$ (c) not reject $\mathrm{H}_{2}$, (b) reject $\mathrm{H}_{2} \rightarrow \mathrm{x}_{1} \Rightarrow \mathrm{x}_{2}$

$\mathrm{E}_{8}$ :(c) not reject $\mathrm{H}_{2}$, (b) not reject $\mathrm{H}_{2}$

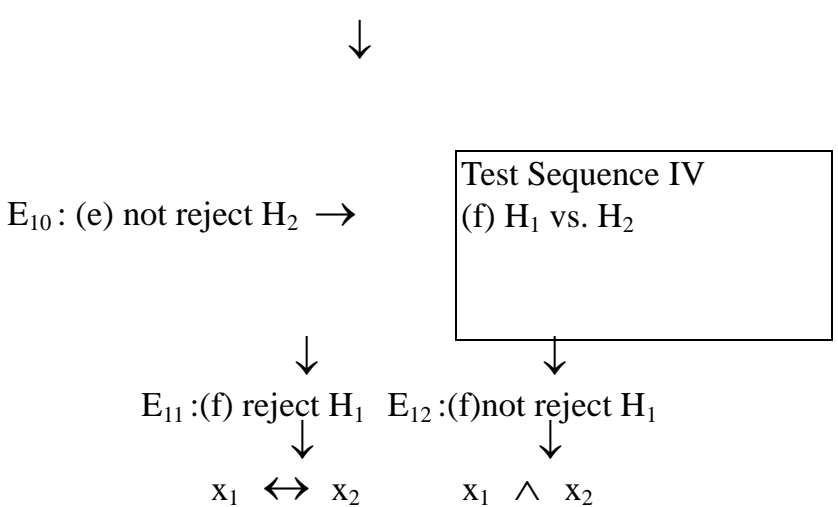

imbalance pressure, we presume that market makers have already known the private information and have accommodate high levels of inventory before the announcements. Inherited to stabilize market, market makers quickly response by conducting countervailing transactions to mitigate volatility. We observe a decreasing pattern of return-order imbalance predictability. From five minutes to fifteen minutes intervals, the percentage of significantly positive lagged-one imbalance falls from $3.57 \%$ to $2.68 \%$ at the $5 \%$ significant level respectively.

\subsection{Conditional contemporaneous return-order imbalances OLS relation}

The empirical results of conditional return-order imbalance relation are reported in Table 4. We look at policies with positive prospect first. In Panel A of Table 4, we find that contemporaneous order imbalances have a significantly positive influence on current return under all significant levels and all time intervals, while the coefficients of lagged-one imbalances are significantly negative. These results are consistent with the argument of "information overweighting" Chordia and Subrahmanyam (2004).

In addition, we can find a convergence path from 5-minutes interval to 15-minutes interval, the percentage of significantly positive coefficients of contemporaneous imbalance declines from $83.93 \%$ to $47.5 \%$ at the $5 \%$ significant level.

\subsection{Dynamic return-order imbalance $\operatorname{GARCH}(1,1)$ relation}

We examine the time varying relation between stock return and order imbalances based on the high

Table 3 Unconditional Lagged Return-Order Imbalance Relation

$$
\mathrm{R}_{\mathrm{t}}=\alpha_{0}+\alpha_{1} \mathrm{OI}_{\mathrm{t}-1}+\alpha_{2} \mathrm{OI}_{\mathrm{t}-2}+\alpha_{3} \mathrm{OI}_{\mathrm{t}-3}+\alpha_{4} \mathrm{OI}_{\mathrm{t}-4}+\alpha_{5} \mathrm{OI}_{\mathrm{t}-5}+\varepsilon_{\mathrm{t}}
$$

where $R_{t}$ is the stock return at time $t$ of the sample stock, $O I_{t-i}, i=1,2,3,4$, and 5, are the lagged order imbalances at time $\mathrm{t}-1, \mathrm{t}-2, \mathrm{t}-3, \mathrm{t}-4$, and $\mathrm{t}-5$ of the sample stocks, $\alpha_{0}, \alpha_{\mathrm{i}}, \mathrm{i}=1,2,3,4$, and 5 , are intercept and coefficients of the corresponding lagged order imbalances, and $\varepsilon_{\mathrm{t}}$ is the residual of the stock return at time t. "Significant" denotes significant at the $5 \%$ level. 
Panel A. Financial policies with positive reaction

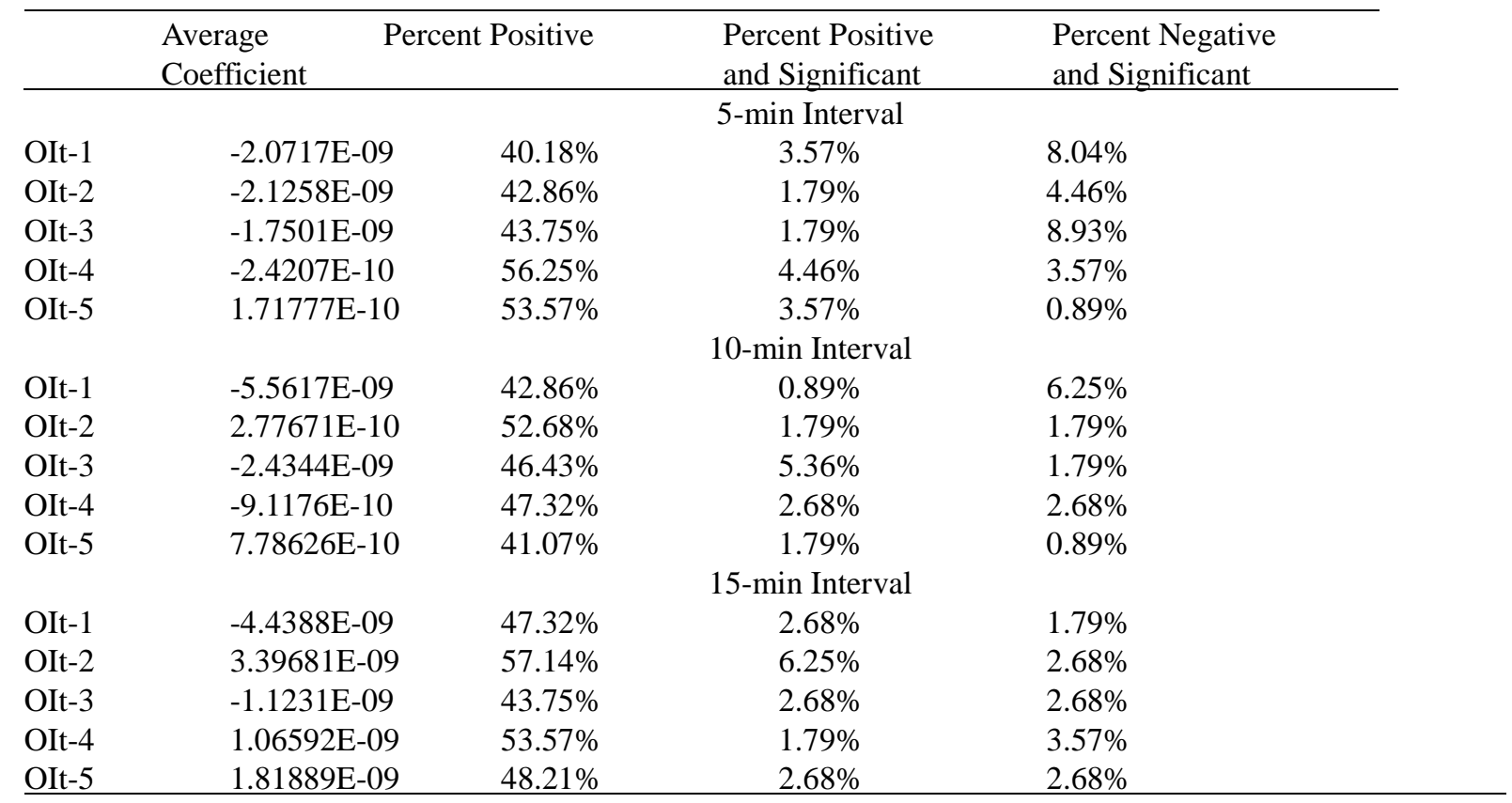

Panel B. Financial policies with negative reaction

\begin{tabular}{|c|c|c|c|c|c|}
\hline \multicolumn{6}{|c|}{ Average coefficient } \\
\hline 5-min & $-5.9172 \mathrm{E}-09$ & $-2.9634 \mathrm{E}-09$ & $2.8235 \mathrm{E}-09$ & $-1.3324 \mathrm{E}-09$ & $-2.5599 \mathrm{E}-09$ \\
\hline 10-min & $-8.6878 \mathrm{E}-09$ & $-1.045 \mathrm{E}-08$ & $-8.041 \mathrm{E}-09$ & $-1.6086 \mathrm{E}-08$ & $-8.8642 \mathrm{E}-09$ \\
\hline 15-min & $-2.7933 \mathrm{E}-08$ & $2.5507 \mathrm{E}-08$ & $-2.95 \mathrm{E}-08$ & $-1.9328 \mathrm{E}-08$ & $-1.2324 \mathrm{E}-08$ \\
\hline
\end{tabular}

volatility in financial crisis. Our empirical results are presented in Table 5. The explaining power of contemporaneous order imbalance, denoted by $\beta$, is declining through time intervals. At the $5 \%$ significant level, the percentage of positive and significant $\beta$ are $56.67 \%, 43.33 \%$, and $30.83 \%$ for 5-, 10-, and $15-\min$ interval respectively.

We find a declining pattern of predictability in return-order imbalance relation in a time varying GARCH model. According to Chordia and Subrahmanyam (2009), volatility may be related to expected returns via traditional risk-return arguments. From the decaying explaining power of the time varying GARCH model, we argue that some of the explaining power in return-order imbalance in regression may end up from volatility, not order imbalance itself. In other words, some risk premium is incorrectly included in the explaining power of order imbalance.

We want to know whether negative prospects share the same pattern. In the three time intervals, positive and significant percents of $\beta$ are all above $50 \%$. Moreover, the percentages do not decline from 5-min interval to 15 -time interval. It doesn't support convergence to market efficiency. It takes a longer time for negative news being incorporated into stock prices during the convergence process. The empirical finding is consistent with Busse and Green (2002). They argue that the response to negative reports is more gradual perhaps due to the higher costs of short selling.

\subsection{Dynamic volatility-order imbalance $\operatorname{GARCH}(1,1)$ relation}

We explore the important role of volatility in return-order imbalance from previous empirical findings. A further investigation of volatility-order imbalance relation has been performed in a time varying GARCH model. The results are exhibited in Table 6.

Table 4 Conditional Contemporaneous Return-Order Imbalance Relation

$$
\mathrm{R}_{\mathrm{t}}=\alpha_{0}+\alpha_{1} \mathrm{OI}_{\mathrm{t}}+\alpha_{2} \mathrm{OI}_{\mathrm{t}-1}+\alpha_{3} \mathrm{OI}_{\mathrm{t}-2}+\alpha_{4} \mathrm{OI}_{\mathrm{t}-3}+\alpha_{5} \mathrm{OI}_{\mathrm{t}-4}+\varepsilon_{\mathrm{t}}
$$

Where $R_{t}$ is the current stock return of the sample stock at time $t$, are the contemporaneous order imbalance at time $t$ and the lagged order imbalances at time $\mathrm{t}-1, \mathrm{t}-2, \mathrm{t}-3$, and $\mathrm{t}-4, \mathrm{t}-5$ of each individual stocks, and $\varepsilon_{\mathrm{t}}$ is the residual of the stock return at time t. "Significant" denotes significant at the 5\% level. 
Panel A. Financial policies with positive reaction

\begin{tabular}{|c|c|c|c|c|}
\hline & $\begin{array}{l}\text { Average } \\
\text { Coefficient }\end{array}$ & ent Positive & $\begin{array}{l}\text { Percent Positive } \\
\text { and Significant }\end{array}$ & $\begin{array}{l}\text { Percent Negative } \\
\text { and Significant }\end{array}$ \\
\hline & & & \multicolumn{2}{|l|}{ 5-min Interval } \\
\hline OIt & 2.99259E-08 & $95.54 \%$ & $83.93 \%$ & $1.79 \%$ \\
\hline OIt-1 & $-4.8303 \mathrm{E}-09$ & $25.89 \%$ & $2.68 \%$ & $13.39 \%$ \\
\hline OIt-2 & $-2.7222 \mathrm{E}-09$ & $40.18 \%$ & $0.00 \%$ & $8.93 \%$ \\
\hline OIt-3 & $-1.5491 \mathrm{E}-09$ & $40.18 \%$ & $0.89 \%$ & $7.14 \%$ \\
\hline \multirow[t]{2}{*}{ OIt-4 } & $-3.5177 \mathrm{E}-10$ & $52.68 \%$ & $5.36 \%$ & $5.36 \%$ \\
\hline & & & \multicolumn{2}{|l|}{ 10-min Interval } \\
\hline OIt & 2.02094E-08 & $88.39 \%$ & $58.93 \%$ & $0.00 \%$ \\
\hline OIt-1 & $-7.2043 \mathrm{E}-09$ & $41.07 \%$ & $2.68 \%$ & $10.71 \%$ \\
\hline OIt-2 & $-5.6102 \mathrm{E}-10$ & $47.32 \%$ & $0.00 \%$ & $1.79 \%$ \\
\hline OIt-3 & $-1.5995 \mathrm{E}-09$ & $49.11 \%$ & $3.57 \%$ & $3.57 \%$ \\
\hline \multirow[t]{2}{*}{ OIt-4 } & $-2.0859 \mathrm{E}-09$ & $42.86 \%$ & $3.57 \%$ & $3.57 \%$ \\
\hline & & & \multicolumn{2}{|l|}{ 15-min Interval } \\
\hline OIt & $2.10818 \mathrm{E}-08$ & $87.50 \%$ & $47.50 \%$ & $0.00 \%$ \\
\hline OIt-1 & $-8.6824 \mathrm{E}-09$ & $34.17 \%$ & $0.83 \%$ & $6.67 \%$ \\
\hline OIt-2 & $2.00065 \mathrm{E}-09$ & $54.17 \%$ & $3.33 \%$ & $2.50 \%$ \\
\hline OIt-3 & $-4.6991 \mathrm{E}-09$ & $35.83 \%$ & $1.67 \%$ & $8.33 \%$ \\
\hline OIt-4 & $8.75468 \mathrm{E}-10$ & $50.00 \%$ & $0.83 \%$ & $4.17 \%$ \\
\hline
\end{tabular}

Panel B. Financial policies with negative reaction

\begin{tabular}{lclccc}
\hline \multicolumn{2}{c}{ Average coefficient } & & & & \\
& OIt & OIt-1 & OIt-2 & OIt-3 & OIt-4 \\
\hline $5 \mathrm{~min}$ & $3.5178 \mathrm{E}-08$ & $-7.0171 \mathrm{E}-09$ & $-3.0771 \mathrm{E}-09$ & $1.8085 \mathrm{E}-09$ & $-1.4576 \mathrm{E}-09$ \\
$10 \mathrm{~min}$ & $2.3663 \mathrm{E}-08$ & $5.98612 \mathrm{E}-09$ & $-2.5551 \mathrm{E}-09$ & $-1.1955 \mathrm{E}-09$ & $-7.4251 \mathrm{E}-09$ \\
$15 \mathrm{~min}$ & $1.5413 \mathrm{E}-08$ & $-1.5678 \mathrm{E}-08$ & $-1.5026 \mathrm{E}-08$ & $-1.688 \mathrm{E}-08$ & $-7.6657 \mathrm{E}-09$ \\
\hline
\end{tabular}

Table 5 Dynamic Return-Order Imbalance GARCH(1,1) Relation

$$
\begin{gathered}
\mathrm{R}_{\mathrm{t}}=\alpha+\beta^{*} \mathrm{OI}{ }_{\mathrm{t}}+\varepsilon_{\mathrm{t}} \\
\varepsilon_{\mathrm{t}} \mid \Omega_{\mathrm{t}-1} \sim \mathrm{N}\left(0, \mathrm{~h}_{\mathrm{t}}\right)
\end{gathered}
$$

$$
\mathrm{h}_{\mathrm{t}}=\mathrm{A}+\mathrm{B} \mathrm{h}_{\mathrm{t}-1}+\mathrm{C} \varepsilon_{\mathrm{t}-1}^{2}
$$

where $\mathrm{R}_{\mathrm{t}}$ is the return at time $\mathrm{t}$, and is defined as $\ln (\mathrm{Pt} / \mathrm{Pt}-1), \mathrm{OI}_{\mathrm{t}}$ denotes the explanatory variable, order imbalance, $\beta$ is the coefficient describing the impact of order imbalance on stock returns, $\varepsilon_{t}$ is the residual value of the stock return at time $\mathrm{t}, \mathrm{h}_{\mathrm{t}}$ is the conditional variance at time $\mathrm{t}, \Omega_{\mathrm{t}-1}$ is the information set in at time $\mathrm{t}-1$. "Significant" denotes significant at the $5 \%$ level.

Panel A. Financial policies with positive reaction

\begin{tabular}{ccll}
\hline$\gamma$ & Positive & $\begin{array}{l}\text { Positive and } \\
\text { significant }\end{array}$ & $\begin{array}{c}\text { Negative and } \\
\text { significant }\end{array}$ \\
\hline 5 -min & $65.83 \%$ & $53.33 \%$ & $1.67 \%$ \\
$10-\min$ & $60.00 \%$ & $39.17 \%$ & $0.00 \%$ \\
$15-\min$ & $58.33 \%$ & $27.50 \%$ & $0.83 \%$ \\
\hline
\end{tabular}

Panel B. Financial policies with negative reaction

\begin{tabular}{rrll}
\hline \multicolumn{1}{c}{$\gamma$} & Positive & \multicolumn{1}{c}{$\begin{array}{c}\text { Positive and } \\
\text { significant }\end{array}$} & $\begin{array}{l}\text { Negative and } \\
\text { significant }\end{array}$ \\
\hline 5 -min & $62.50 \%$ & $50.00 \%$ & $0.00 \%$ \\
$10-\min$ & $100.00 \%$ & $62.50 \%$ & $0.00 \%$ \\
$15-\min$ & $75.00 \%$ & $50.00 \%$ & $0.00 \%$ \\
\hline
\end{tabular}

Table 6 Dynamic Volatility-Order Imbalance GARCH(1,1) Relation

$$
\begin{gathered}
\mathrm{R}_{\mathrm{t}}=\alpha+\varepsilon_{\mathrm{t}} \\
\varepsilon_{\mathrm{t}} \mid \Omega_{\mathrm{t}-1} \sim \mathrm{N}\left(0, \mathrm{~h}_{\mathrm{t}}\right) \\
\mathrm{h}_{\mathrm{t}}=\mathrm{A}+\mathrm{B} \mathrm{h}_{\mathrm{t}-1}+\mathrm{C} \varepsilon_{\mathrm{t}-1}^{2}+\gamma * \mathrm{OI}_{\mathrm{t}}
\end{gathered}
$$

Where $\mathrm{R}_{\mathrm{t}}$ is the return at time $\mathrm{t}$, and is defined as $\ln (\mathrm{Pt} / \mathrm{Pt}-1), \mathrm{OI}_{\mathrm{t}}$ is the explanatory variable, order imbalance, $\gamma$ is the 
coefficient describing the impact of order imbalance on stock volatility, $\varepsilon_{t}$ is the residual value of the stock return at time $\mathrm{t}, \mathrm{h}_{\mathrm{t}}$ is the conditional variance at time $\mathrm{t}, \Omega_{\mathrm{t}-1}$ is the information set in at time $\mathrm{t}-1$. "Significant" denotes significant at the $5 \%$ level.

Panel A. Financial policies with positive reaction

\begin{tabular}{rlll}
\hline \multicolumn{1}{r}{$\gamma$} & Positive & $\begin{array}{l}\text { Positive and } \\
\text { significant }\end{array}$ & $\begin{array}{l}\text { Negative and } \\
\text { significant }\end{array}$ \\
\hline 5 -min & $44.64 \%$ & $6.25 \%$ & $7.14 \%$ \\
$10-$ min & $27.68 \%$ & $4.46 \%$ & $8.04 \%$ \\
$15-$ min & $34.82 \%$ & $1.79 \%$ & $0.00 \%$ \\
\hline
\end{tabular}

Panel B. Financial policies with negative reaction

\begin{tabular}{rccc}
\hline$\gamma$ & Positive & $\begin{array}{l}\text { Positive and } \\
\text { significant }\end{array}$ & $\begin{array}{l}\text { Negative and } \\
\text { significant }\end{array}$ \\
\hline 5 -min & $37.50 \%$ & $12.50 \%$ & $12.50 \%$ \\
$10-$ min & $50.00 \%$ & $12.50 \%$ & $0.00 \%$ \\
$15-$ min & $12.50 \%$ & $0.00 \%$ & $0.00 \%$ \\
\hline
\end{tabular}

Intuitively, a large order imbalance is positively associated with a large volatility. Therefore, we expect a positive relation between volatility and order imbalance. However, the results presented in Panel B show that the relation is not as significant as we have expected. At 5\% significant level, 6.25\%, 4.46\%, and $1.79 \%$ of order imbalances have significant positive effect on price volatility for 5-, 10-, 15-min interval respectively.

The weak connection of imbalance on volatility implies that market makers are capable of mitigating volatility in financial policy announcements. The empirical finding that percentage of significantly positive coefficient declines from 5-min to 15-min interval shows that the market makers do have the ability to do price stabilization even in financial crisis.

From the empirical results of policies with negative prospect, we find that, on average, the percentages of significantly positive and negative coefficients are larger than those with positive prospect. Many previous empirical studies show that the volatility of stock returns may be asymmetrically in responses to bad and good news. More specifically, they argue that the volatility of stock returns is usually higher in bad times than in good times. We also observe that significant positive impact of order imbalance on volatility fades away within 15 minutes in convergence process.

\subsection{Order imbalance based trading strategy}

From previous empirical findings of return-order imbalance, we develop an intra-day imbalance based trading strategy to test market efficiency through financial policy announcements. We truncated $10 \%$ largest order imbalance to rule out noise trades. We buy positive order imbalances and short negative order imbalance. The results are exhibited in Panel A of Table 7.

We earn a daily return of $-0.17 \%,-0.66 \%$, and $-0.27 \%$ for 5 -min, 10 -min, and 15 -min time intervals, respectively. One tail Z-test was used to examine whether we earn a positive return. The result is listed in section 1 of Panel $\mathrm{B}$. The p-values are $0.6384,0.9934$, and 0.9182 for 5-, 10-, and 15-min intervals respectively. It is very obvious that our strategy fails to earn a significantly positive return. We then adopt a paired t-test to examine whether our trading strategy is capable of beating the markets. From section 2 of Panel B, we find that the p-values of this test are 0.000209, 0.030904 , and 0.328562 for 5-, 10-, and 15-min intervals respectively. At the 5\% significant level, the trading strategy based on 10-min intervals is able to beat the market. Moreover, the return of trading strategy based 5-min intervals is significantly higher than the open-to-close return at $1 \%$ significantly level.

Finally, we use a paired t-test in section 3 to examine whether there is significant difference among the Table 7 Trading Profit under the Basis of Trading Price

Panel A. Returns compared with zero

$$
\text { 1. }\left\{\begin{array}{l}
\mathrm{H}_{0}: \mu_{\mathrm{i}} \leq 0 \\
\mathrm{H}_{1}: \mu_{\mathrm{i}}>0
\end{array}\right.
$$


Where $\mu_{\mathrm{i}}$ is the return of the trading strategy, i denotes 5-, 10-, and 15-min interval

\begin{tabular}{ll}
\hline & P-value \\
\hline 5-min Return of strategy & 0.6384 \\
10-min Return of strategy & 0.9934 \\
15-min Return of strategy & 0.9182 \\
\hline
\end{tabular}

Panel B. Returns compared with returns of buy-and-hold strategy

2. $\left\{\begin{array}{l}\mathrm{H}_{0}: \mu_{\mathrm{i}} \leq \mu_{0} \\ \mathrm{H}_{1}: \mu_{\mathrm{i}}>\mu_{0}\end{array}\right.$

Where $\mu_{\mathrm{i}}$ is the return of the trading strategy, i denotes 5-, 10-, and 15-min interval

$\mu_{0}$ is the original open-to -close return

\begin{tabular}{lll}
\hline & Mean & P-value \\
\hline Original open-to-close return & \multicolumn{1}{c}{0.0257} & \\
5-min Return of strategy & -0.0018 & 0.0002 \\
10-min Return of strategy & 0.0146 & 0.0309 \\
15-min Return of strategy & -0.0142 & 0.3285 \\
\hline
\end{tabular}

Panel C. Differences in returns among the three intervals

3. $\left\{\begin{array}{l}\mathrm{H}_{0}: \mu_{\mathrm{i}}=\mu_{\mathrm{j}} \\ \mathrm{H}_{1}: \mu_{\mathrm{i}} \neq \mu_{\mathrm{j}}\end{array}\right.$

Where $\mu_{\mathrm{i}}$ is the return of the trading strategy

$\mathrm{i}, \mathrm{j}$ denotes 5-, 10-, and 15-min interval, $\mathrm{i} \neq \mathrm{j}$

\begin{tabular}{lll}
\hline P-value & 5-min Return & 10-min Return \\
\hline 5-min Return & & \\
10-min Return & 0.0322 & \\
15-min Return & 0.0019 & 0.1241 \\
\hline
\end{tabular}

three different intervals (5-, 10, and 15-min). The low p-values show that there is a significant difference between 5-min and 10-min intervals and between 5-min interval and 15-min interval. The empirical results self-explain a decreasing explanatory power of contemporaneous imbalance from 5-min to 15-min interval in our previous GARCH studies.

We perform a similar trading strategy based on one period delay trades. The results are presented in Panel A of Table 8 as well. Panels $\mathrm{C}$ of Tables 7 and 8 report the result of the three hypothesis test. From the p-value in section 1 of Panel $\mathrm{C}$, we find the same result as the previous trading strategy. In addition, the result of paired t-test shows that, at the $1 \%$ significant level, this strategy cannot beat the original open-to-close return for the three different time intervals, either. And only at the 5\% significant level, there exists a significant performance difference between 5-min and 15-min interval.

In conclusion, we cannot earn a significantly positive return through order imbalance based trading strategy in financial policy announcements in financial crisis. However, imbalance based trading strategies for 5 and 10 minutes time intervals are capable of beating the market. However, the abnormal returns disappear when we use one period delay trades. And the significant differences between trading strategies self-explain convergence to market efficiency in financial policy announcements during financial crisis.

\subsection{Causality relation in explaining return-order imbalance dynamics}

To explore dynamic return-order imbalance relationship during the price formation process, we employ

Table 8 Trading Profit under the Basis of (delayed buying timing)

Panel A: Returns compared with zero

1. $\left\{\begin{array}{l}\mathrm{H}_{0}: \mu_{\mathrm{i}} \leq 0 \\ \mathrm{H}_{1}: \mu_{\mathrm{i}}>0\end{array}\right.$ 
Where $\mu_{\mathrm{i}}$ is the return of the trading strategy, i denotes 5-, 10-, and 15-min interval

\begin{tabular}{ll}
\hline & P-value \\
\hline 5-min Return of strategy & 1.0000 \\
10-min Return of strategy & 1.0000 \\
15-min Return of strategy & 1.0000 \\
\hline
\end{tabular}

Panel B. Returns compared with returns of buy-and-hold strategy

$$
\text { 2. }\left\{\begin{array}{l}
\mathrm{H}_{0}: \mu_{\mathrm{i}} \leq \mu_{0} \\
\mathrm{H}_{1}: \mu_{\mathrm{i}}>\mu_{0}
\end{array}\right.
$$

Where $\mu_{\mathrm{i}}$ is the return of the trading strategy, i denotes 5-, 10-, and 15-min interval

$\mu_{0}$ is the original open-to-close return

\begin{tabular}{lcl}
\hline & Mean & \multicolumn{1}{c}{ P-value } \\
\hline Original open-to-close return & -0.0257 & \\
5-min Return of strategy & -0.0235 & 0.3737 \\
10-min Return of strategy & -0.0330 & 0.4498 \\
15-min Return of strategy & -0.0416 & 0.0137 \\
\hline
\end{tabular}

Panel C. Differences in returns among the three intervals

$$
\text { 3. }\left\{\begin{array}{l}
H_{0}: \mu_{i}=\mu_{j} \\
H_{1}: \mu_{i} \neq \mu_{j}
\end{array}\right.
$$

Where $\mu_{\mathrm{i}}$ is the return of the trading strategy

$\mathrm{i}, \mathrm{j}$ denotes 5-, 10-, and 15-min interval , $\mathrm{i} \neq \mathrm{j}$

\begin{tabular}{lll}
\hline P-value & 5-min Return & 10-min Return \\
\hline 5-min Return & & \\
10-min Return & 0.3381 & \\
15-min Return & 0.0195 & 0.2768 \\
\hline
\end{tabular}

a nested causality approach. In order to investigate the dynamic relationship between two variables, we impose the constraints in the upper panel of Table 1 for the VAR model. In Table 9, we present the empirical results of the tests of the hypotheses for the dynamic relationship in Table 2. For the entire sample, we show that the unidirectional relationship from returns to order imbalances is $12.50 \%$ of the sample firms for the entire sample, while the unidirectional relationship from order imbalances to returns is $25.00 \%$. The percentage of firms that fall into the independent category is $0.00 \%$. Moreover, $50.00 \%$ of firms exhibit a contemporaneous relationship between returns and order imbalances. Finally, $12.50 \%$ of firms exhibit a feedback relationship between returns and order imbalances. The percentage of firms exhibiting a unidirectional relationship from order imbalances to returns is larger than that exhibiting such a unidirectional relationship from returns to order imbalances, suggesting that order imbalances constitute a better indicator for predicting future returns. This finding is consistent with many articles, which document that future daily returns could be predicted by daily order imbalances (Brown et al., 1997; Chordia et al., 2004). In addition, the percentage of firms exhibiting a contemporaneous relationship is larger than that of the corresponding percentage reflecting a feedback relationship, indicating the interaction between returns and order imbalances in the current period is larger than that over the whole period.

Table 9 Dynamic nested causality relationship between returns and order imbalances

The causal relationships are defined as follows: $\wedge$ represents independency; $\langle-\rangle$ is the contemporaneous relationship; $\neq>$ is the negation of the unidirectional relationship; $<=>$ is the feedback relationship; $\neq>>$ is the negation of a strong unidirectional relationship where $\sigma_{12}=\sigma_{21}=0$; and $\langle<=>>$ is a strong feedback relationship where $\sigma_{12}=\sigma_{21}=0$. The percentage explained by each dynamic relationship is based on a $5 \%$ significance level of tests.

\begin{tabular}{llllll}
\hline & $x_{1} \wedge x_{2}$ & $x_{1}<->x_{2} \quad x_{1} \Rightarrow x_{2} \quad x_{1} \Leftarrow x_{2} \quad x_{1}<=>x_{2}$ \\
\hline All trade size & $0.00 \%$ & $50.00 \%$ & $12.50 \%$ & $25.00 \%$ & $12.50 \%$ \\
\hline
\end{tabular}




\section{Conclusion}

During 2008 financial crisis, investors suffered from volatile stock markets. We examine convergence to market efficiency through financial policy announcements. We collect important financial policy announcements from Sep. 15, to Dec. 31, 2008 during financial crisis. We run an unconditional lagged return-order imbalances regression. Surprisingly, significantly negative percentage of lagged-one imbalance is higher than positive one. The possible explanation is that market makers are able to accommodate high inventories in announcements We find a significantly positive contemporaneous return-order imbalances relation, while the coefficients of lagged-one imbalances are significantly negative. These results are consistent with "information over-weighting" Chordia and Subrahmanyam (2004). In addition, we find a convergence path from 5-minutes interval to 15-minutes interval.

To explore the importance of volatility in return-order imbalance, especially in a volatile market in financial crisis, we employ a time varying GARCH. WE document a decaying pattern in GARCH. It implies that some of the explaining ability may be attributed to risk premium. We make a further step to investigate volatility-order imbalance relation through a time varying GARCH. A significantly positive relation is expected because, intuitively, a large volatility is positively associated with a large order imbalance. However, the empirical results show an insignificant relation between volatility and order imbalance. We cast on market maker behaviors because market makers have the capability to mitigate volatility through high accommodations even in financial policy announcements.

Based on our empirical results, we develop an imbalance based trading strategy to beat the market. We find that only strategies for five and ten minute intervals can beat the original open-to-close return. However, if we make an one period delay trades, the abnormal returns disappear. Moreover, all strategies cannot earn a significant positive return in financial crisis.

In order to explain the story behind imbalance based trading strategy, we employ a nested causality approach to examine return-order imbalance dynamics during the price-formation process. The results self-explain our imbalance-based trading strategy.

\section{References}

Andrade, S. C., Chang, C., \& Seasholes, M. S. (2008). Trading imbalances, predictable reversals, and cross-stock price pressure. Journal of Financial Economics, 88(2), 406-423. http://dx.doi.org/10.1016/j.jfineco.2007.04.005

Barclay, M. J., \& Warner, J. B. (1993). Stealth trading and volatility. Journal of Financial Economics, 34(3), 281-305. http://dx.doi.org/10.1016/0304-405X(93)90029-B

Brown, P., Walsh, D., \& Yuen, A. (1997). The interaction between order imbalance and stock price. Pacific-Basin Finance Journal, 5(5), 539-557. http://dx.doi.org/10.1016/S0927-538X(97)00019-X

Busse, J. A., \& Green, T. C. (2002). Market efficiency in real time. Journal of Financial Economics, 65(3), 415-437. http://dx.doi.org/10.1016/S0304-405X(02)00148-4

Chen, C., \& Wu, C. (1999). The dynamics of dividends, earnings and prices: Evidence and implications for dividend smoothing and signaling. Journal of Empirical Finance, 6(1), 29-58. http://dx.doi.org/10.1016/S0927-5398(98)00008-5

Chordia, T., \& Subrahmanyam, A. (2004). Order imbalance and individual stock returns: Theory and evidence. Journal of Financial Economics, 72(3), 485-518. http://dx.doi.org/10.1016/S0304-405X(03)00175-2

Chordia, T., Roll, R., \& Subrahmanyam, A. (2005). Evidence on the speed of convergence to market efficiency. Journal of Financial Economics, 76(2), 271-292. http://dx.doi.org/10.1016/j.jfineco.2004.06.004

Chordia, T., Huh, S. W., \& Subrahmanyam, A. (2009). Theory-based illiquidity and asset pricing. The Review of Financial Studies, 22(9), 3629-3668. http://dx.doi.org/10.1093/rfs/hhn121

Foster, F. D., \& Viswanathan, S. (1994). Strategic trading with asymmetric informed traders and long-lived information. Journal of Financial and Quantitative Analysis, 29(4), 499-518. http://dx.doi.org/10.2307/2331107

Foster, F. D., \& Viswanathan, S. (1996). Strategic trading when agents forecast the forecasts of others. Journal of Finance, 51(4), 1437-1478. http://dx.doi.org/10.1111/j.1540-6261.1996.tb04075.x

Grossman, S. (1976). On the efficiency of competitive stock markets where trades have diverse information. Journal of Finance, 31(2), 573-585. http://dx.doi.org/10.1111/j.1540-6261.1976.tb01907.x

Grossman, S. J., \& Stiglitz, J. E. (1980). On the impossibility of informationally efficient markets. The American Economic Review, 70(3), 393-408. http://www.jstor.org/stable/1805228

Hillmer, S. C., \& Yu, P. L. (1979). The market speed of adjustment to new information. Journal of Financial Economics, 7(4), 321-345. http://dx.doi.org/10.1016/0304-405X(79)90002-3

Holden, C. W., \& Subrahmanyam, A. (1992). Long-lived private Information and imperfect competition. Journal of 
Finance, 47(1), 247-270. http://dx.doi.org/10.1111/j.1540-6261.1992.tb03985.x

Kyle, A. S. (1985). Continuous auctions and insider trading. Econometrica, 53(6), 1315-1335. http://dx.doi.org/10.2307/1913210

Lee, C. M. C., \& Ready, M. J. (1991). Inferring trade direction from intraday data. Journal of Finance, 46(2), 733-746. http://dx.doi.org/10.1111/j.1540-6261.1991.tb02683.x

Malkiel, B. G., \& Fama, E. F. (1970). Efficient capital markets: a review of theory and empirical work. The Journal of Finance, 25(2), 383-417. http://dx.doi.org/10.1111/j.1540-6261.1970.tb00518.x

Wang, J. (1993). A model of intertemporal asset prices under asymmetric information. Review of Economic Studies, 60(2), 249-282. http://dx.doi.org/10.2307/2298057

Wang, J. (1994). A model of competitive stock trading volume. Journal of Political Economy, 102(1), 127-168. http://dx.doi.org/10.1086/261924

Appendix 1 Financial Policies

Panel A. Policies with Positive Reaction

\begin{tabular}{|c|c|}
\hline $\begin{array}{l}\text { Announcement } \\
\text { Date }\end{array}$ & Financial Policy \\
\hline 2008/9/16 & $\begin{array}{l}\text { The Federal Reserve Board, with the full support of the Treasury Department, authorized the } \\
\text { Federal Reserve Bank of New York to lend up to } \$ 85 \text { billion to the American International } \\
\text { Group (AIG). }\end{array}$ \\
\hline 2008/9/19 & $\begin{array}{l}\text { The Federal Reserve Board on Friday approved two interim final rules in connection with its } \\
\text { initiative to provide liquidity to markets by extending loans to banking organizations to } \\
\text { finance their purchases of high-quality asset-backed commercial paper (ABCP) from money } \\
\text { market mutual funds. }\end{array}$ \\
\hline 2008/9/22 & $\begin{array}{l}\text { Approval of the applications of Goldman Sachs and Morgan Stanley to become bank holding } \\
\text { companies. }\end{array}$ \\
\hline 2008/9/25 & U.S. Senate annouced that it basically agree with the principle of government's bailout plan. \\
\hline 2008/9/29 & $\begin{array}{l}\text { Banking operations of Wachovia Corp., which is headquartered in Charlotte, N.C., are being } \\
\text { acquired by Citigroup Inc. Citigroup will acquire the bulk of Wachovia's assets and liabilities, } \\
\text { including five depository institutions and assume senior and subordinated debt of Wachovia. }\end{array}$ \\
\hline & $\begin{array}{l}\text { The Congress draw up an outline agreeing to preliminarily spend } \$ 350 \text { billion to buy banks } \\
\text { risky asset. }\end{array}$ \\
\hline 2008/10/2 & The government's financial bailout plan was approved by the U.S. Senate. \\
\hline 2008/10/3 & The revised bailout plan was approved by the House of Representatives. \\
\hline \multirow[t]{2}{*}{ 2008/10/6 } & $\begin{array}{l}\text { The Federal Reserve Board on Monday announced that it will begin to pay interest on } \\
\text { depository institutions' required and excess reserve balances. }\end{array}$ \\
\hline & The Federal Reserve will offer $\$ 150$ billion in 85 -day credit through its Term Auction Facility. \\
\hline 2008/10/7 & Approval of proposal by UFJ Financial Group to acquire voting shares of Morgan Stanley. \\
\hline 2008/10/8 & $\begin{array}{l}\text { The Federal Open Market Committee has decided to lower its target for the federal funds rate } \\
50 \text { basis points to } 1-1 / 2 \text { percent. }\end{array}$ \\
\hline 2008/10/8 & $\begin{array}{l}\text { The Federal Reserve Board has authorized the Federal Reserve Bank of New York to borrow } \\
\text { securities from certain regulated U.S. insurance subsidiaries of the American International } \\
\text { Group (AIG). Under this program, the New York Fed will borrow up to } \$ 37.8 \text { billion in }\end{array}$ \\
\hline
\end{tabular}




\begin{tabular}{|c|c|}
\hline & ivestment-grade, fixed-income securities from AIG in return for cash collateral. \\
\hline $2008 / 10 / 12$ & $\begin{array}{l}\text { The Federal Reserve Board on Sunday announced its approval of the application and notice } \\
\text { under sections } 3 \text { and } 4 \text { of the Bank Holding Company Act by Wells Fargo \& Company, San } \\
\text { Francisco, California, to acquire Wachovia Corporation and its subsidiary banks. }\end{array}$ \\
\hline $2008 / 10 / 14$ & $\begin{array}{l}\text { Joint Statement by Treasury, Federal Reserve, and FDIC: First, Treasury is announcing a } \\
\text { voluntary capital purchase program. Second, Secretary Paulson signed the systemic risk } \\
\text { exception to the FDIC Act, enabling the FDIC to temporarily guarantee the senior debt of all } \\
\text { FDIC-insured institutions and their holding companies, as well as deposits in non-interest } \\
\text { bearing deposit transaction accounts. Nine major financial institutions have already agreed to } \\
\text { participate in both the capital purchase program and the FDIC guarantee program. Third, the } \\
\text { Federal Reserve has announced further details of its Commercial Paper Funding Facility } \\
\text { (CPFF) program, which provides a broad backstop for the commercial paper market. }\end{array}$ \\
\hline $2008 / 10 / 29$ & $\begin{array}{l}\text { The Federal Open Market Committee decided today to lower its target for the federal funds } \\
\text { rate } 50 \text { basis points to } 1 \text { percent. }\end{array}$ \\
\hline 2008/11/10 & $\begin{array}{l}\text { Approval of proposal by American Express Company and American Express Travel Related } \\
\text { Services Company to become bank holding companies }\end{array}$ \\
\hline $2008 / 11 / 24$ & $\begin{array}{l}\text { The U.S. government on Sunday entered into an agreement with Citigroup to provide a } \\
\text { package of guarantees, liquidity access, and capital. }\end{array}$ \\
\hline \multirow[t]{2}{*}{$2008 / 11 / 25$} & $\begin{array}{l}\text { The Federal Reserve Board announced the creation of the Term Asset-Backed Securities Loan } \\
\text { Facility (TALF), under which the Federal Reserve Bank of New York (FRBNY) will lend up } \\
\text { to } \$ 200 \text { billion on a non-recourse basis to holders of certain AAA-rated ABS backed by newly } \\
\text { and recently originated consumer and small business loans. }\end{array}$ \\
\hline & $\begin{array}{l}\text { The Federal Reserve announced that it will initiate a program to purchase the direct } \\
\text { obligations of housing-related government-sponsored enterprises (GSEs), Fannie Mae, } \\
\text { Freddie Mac, and the Federal Home Loan Banks, up to } \$ 100 \text { billion, and also purchase up to } \\
\$ 500 \text { billion mortgage-backed securities (MBS) backed by Fannie Mae, Freddie Mac, and } \\
\text { Ginnie Mae. }\end{array}$ \\
\hline $2008 / 11 / 26$ & Approval of proposal by Bank of America to acquire Merrill Lynch. \\
\hline $2008 / 12 / 16$ & $\begin{array}{l}\text { The Federal Open Market Committee decided today to establish a target range for the federal } \\
\text { funds rate of } 0 \text { to } 1 / 4 \text { percent. }\end{array}$ \\
\hline $2008 / 12 / 22$ & $\begin{array}{l}\text { The Federal Reserve Board announced its approval of the application submitted by CIT Group } \\
\text { Inc., New York, New York, to become a bank holding company on conversion of CIT Bank, } \\
\text { Salt Lake City, Utah, to a state bank. }\end{array}$ \\
\hline
\end{tabular}

Panel B. Policies with Negative Reaction

\begin{tabular}{|c|c|}
\hline $\begin{array}{c}\text { Announcement } \\
\text { Date }\end{array}$ & Financial Policy \\
\hline $2008 / 9 / 30$ & The House of Representatives voted down the government's financial bailout plan. \\
\hline
\end{tabular}

\section{(cc) $\mathrm{BY}$}

This work is licensed under a Creative Commons Attribution 3.0 License. 